\title{
Research on the Teaching Reform of Cross-border E-Commerce Course Based on the Double-increment Ability Training
}

\author{
Author unit: Tianjin Maritime College \\ Author's name: Hexiang Wang \\ postal code: 300350
}

\begin{abstract}
Keywords: cross-border e-commerce; talent training; teaching reform
\end{abstract}
\begin{abstract}
With the rapid development of Internet technology, the e-commerce industry continues to rise, the demand for talents has gradually increased, and the opening of e-learning courses in colleges and universities has also become a hot topic. Under the background of Internet technology development, "Internet+ " is in various industries . In China, it is widely used . Cultivating talents for dual-creativity is also a key point in cross-border e-commerce courses teaching in colleges and universities. It is necessary to analyze the teaching objectives of the course of light of the actual situation of enterprise development. This article will analyze the teaching reform of cross-border e-commerce courses based on the double-invasion ability training and propose corresponding measures .
\end{abstract}

\section{Introduction}

At present, China's social and economic development, the continuous transformation and upgrading of the national economy, provide certain potential for innovation for the development of the economy, and proposes a "double-creation" major strategy. Through continuous reforms, the government gradually promotes the implementation of the "Internet Plus" strategy. It is necessary to provide certain conditions for the innovative development of the economy and to promote the implementation of the dual-creation strategy by improving the country's economy and policies. Faced with the current new social development situation and environment, the demand for talents is also increasing. The development of talents also needs to adapt to the current social development situation. Cross-border e-commerce is an important part of the e-commerce profession, and it is also a theoretical and practical course. The exploration of teaching modes needs to be adjusted according to the current economic development situation. It is necessary to adapt to the "Internet+". Strategy to develop the cross-border talents that companies need.

\section{The Status Quo of the Development of Cross-Border E-Commerce Industry in China}

In recent years, the internationalized economy has developed rapidly, the links between countries have gradually strengthened, and China's foreign trade has also shown a growing trend. The development of the cross-border e-commerce industry is also showing a steadily rising trend . According to relevant data investigations, The transaction scale of China's cross-border e-commerce has increased year by year, from the initial 0.8 trillion to 4.8 trillion, and in 2015 , although the economic development is in a depressed state, the absolute level of cross-border e-commerce transactions has increased significantly, and In the development of foreign trade, the penetration rate of cross-border e-commerce is also continuously increasing [1] . With the continuous development of China's economy and continuous development and progress of the technology industry, cross-border e-commerce has been showing a growing trend, and it is expected that the transaction scale of cross-border e-commerce will reach 12 trillion in 2020 . In the process of rapid development of cross-border e-commerce, the demand for talents is also increasing. The requirements for talents are also increasing, providing more opportunities for innovation and development of trade professionals, and the e-commerce business under the new situation. The contradiction in the development of talent demanded has gradually shown that 
cross-border electricity traders are still the current development gap, but cross-border electricity traders cannot adapt to the current social development . They cannot adapt to job demands in actual work and need to explore cross-border electricity. The cultivation mode of merchants, according to the actual needs of the job, focuses on the reform of the traditional teaching model, so that students can better adapt to the needs of cross-border e-commerce jobs [2].

\section{Problems in Cross-Border E-Commerce Professional Teaching}

At present, the cross-border e-commerce course is a newly established course, and the construction time is relatively short. Along with the continuous development of the current Internet technology, the development characteristics of cross-border e-commerce in different periods are different, and the teaching of the course is different. The form is also constantly changing. The traditional classroom teaching methods and content can no longer adapt to the current social development trends, and the teaching effect will not achieve the goal of the double-increment ability training . The continuous development and infiltration of cross-border e-commerce in international trade has also become a new growth point of the promotion of China's economic growth . The problems existing on traditional e-commerce professional teaching are :

\subsection{Lack Understanding of Professional Knowledge}

As the cross-border e-commerce professional is also in its early stage of development, a systematic teaching system has not yet been formed. Students do not have enough professional cognitive ability, learning is relatively blind, and the relevant theoretical knowledge is not well-understood . It is always in the process of learning. In a passive position, students ' interest in learning is not high, there is no clear learning goal, and the teaching effect is not obvious enough [3] . The main factor are that the e-commerce professional teaching and practice do not have a good docking. The students ' understanding is not in place. The lack of professional planning for the courses does not help students realize the importance of professional learning .

\subsection{Professional Assessment Mechanism is Not Perfect}

For the development of cross-border e-commerce and the cultivation of talents, the scientific assessment mechanism is also an important means to promote the progress of students. There are also various ways for the assessment of professional courses, including the writing of experimental reports and training reports. The existing assessment mechanism cannot achieve the expected teaching results. The form of practical training assessment is also capable of assessing the students' theoretical knowledge and practice, cultivating students' innovative ability, stimulating students' interest in learning, and laying a foundation for the students' future entrepreneurship. . However, there are many problems in the actual training of students, lack of practical arguments, and the content of the report is relatively simple.

\section{Cross-border E-commerce Teaching Reform Measures Based on Double-invasion Ability Training}

\subsection{The Teaching Target of Cultivating Students Based on Innovation and Entrepreneurship}

The cultivation of innovation and entrepreneurship is also a trend in current social development. By improving students' professional knowledge and logical thinking ability, students are trained to become complex talents.

\subsubsection{Clear Basic Knowledge of Cross-Border E-commerce}

In cross-border e-commerce courses, students need to first understand the basic knowledge of cross-border e-commerce and future development trends. It is necessary to make clear the future development prospects of cross-border e-commerce, and to have a preliminary understanding of the subject's learning, and to cross-border The basic modes of e-commerce learning are B2B and B2C, two modes. They are familiar with the platform and operational flow of cross-border e-commerce, 
and have a preliminary understanding of cross-border e-commerce professional [4] .

\subsubsection{Focus on Cultivating Students' Awareness of Innovation and Entrepreneurship}

In the cross-border e-commerce teaching, in the teaching experiment, we should pay attention to the cultivation of students' innovative ability, train the students' thinking ability, guide the students through relevant cases, and cultivate students' sense of innovation through various Simulate the operation of the software so that students can become familiar with the basic cross-border e-commerce operation process and stimulate students' entrepreneurial initiative.

\subsubsection{Develop Students Ability to Solve Practical Problems}

In the school's cross-border e-commerce education, all e-commerce platforms, such as Dunhuang.com and AliExpress, are used to enable students to become familiar with the basic processes of operations and improve their ability to solve practical problems. Provide opportunities for internship visits and provide rich experience for future business ventures.

\subsection{Strengthen Practical Teaching}

The teaching of cross-border e-commerce courses needs to enhance the enthusiasm for students through practical means, and encourage students to participate in cross-border e-commerce competitions, including actual combat simulation and essay competitions, so that students can feel the innovative atmosphere of cross-border e-commerce, and Quickly grasp relevant knowledge and enhance innovation capabilities . For example, actual combat simulation can realize the hardships of starting a business, inspire students ' interest in learning, and cultivate their entrepreneurial awareness . Using cross-border e-commerce platforms, Amazon, wish and other platforms to cooperate, select some of these platforms as training, can also provide a pure foreign language environment on business English students .

\subsection{Strengthen Cooperation Between Schools and Enterprises}

For cross-border e-commerce teaching, it is necessary to strengthen the practice. Through cooperation between schools and enterprises, enterprises provide corresponding facilities and equipment. Students can master basic professional skills in practice and experience the atmosphere that cannot be experienced in simulation training. The e-commerce company provides a platform combining theory with practice. The school provides enterprises with the appropriate amount of internship talents, establishes long-term cooperative relationships with the enterprise, realizes the rational allocation of resources, and accumulates rich experience for the students' future entrepreneurship. For example, the school provides students with entrepreneurial atmosphere on the Maker platform. By inviting management personnel from relevant companies to train teachers, professional teachers of cross-border e-commerce can continuously access information in the market and industry and deepen their own teaching knowledge. Through practical training, we fully understand international logistics, customs clearance, tax rebates, etc., and familiarize ourselves with a complete set of service procedures, and handle the processing of late-stage orders.

\section{Conclusion}

In summary, under the background of the rapid development of cross-border e-commerce, the training of cross-border electricity merchants also needs to be continuously strengthened. The training of cross-border electricity merchants needs to pay attention to the training of talents, and the teaching plan needs to be adapted. The needs of job development, adhere to the implementation of the "double-creation" strategy. To provide students with a good business environment and atmosphere, to meet the needs of the talent market at all times, to enhance the development of students' innovative and entrepreneurial abilities, to cultivate talents that meet the needs of society, and to help economic development. 


\section{References:}

[1]. Sun Congzhong. Exploration of SPOC Teaching Model for Higher Vocational "Cross-border E-commerce" Curriculum_- Taking Ningbo City Vocational and Technical College as an Example[J].Journal of Wenzhou Vocational and Technical College,2016,1601:86-89+96.

[2]. Lin Rongrong, Zhao Heqin. Discussion on the Cultivation Model of Cross-border Electricity Merchants under the Background of "Internationalization" [J]. Chinese Commercial Theory, 2017, 34: 185-186.

[3]. Wu Pingping. Research on the Teaching Reform and Practice of "International Trade Practice" under the Background of Cross-border E-commerce [J]. Times Finance, 2017, 30: 289-290.

[4]. Yin Jialing. Research on the "Three-stage" Project Teaching Reform of Cross-border E-Commerce Based on School-enterprise Cooperation [J]. Modern Economic Information, 2017, 22:454+456.

[5]. Guan Haojie. Research on the Teaching Reform of Cross-border E-Commerce Curriculum Based on the Double-increase Ability Training [J]. Market Weekly (Theoretical Studies), 2017, 04:153-154. 